\title{
Regional Government Strategy Design in Tanjung Bira Tourism Development in Bulukumba Regency
}

\author{
Andi Risma Jaya ${ }^{1}$, Armin Arsyad ${ }^{1}$, Suriadi Lambali ${ }^{1}$, Muhammad Tang Abdullah ${ }^{1}$ \\ ${ }^{1}$ Public Administration, Faculty of Social and Political Sciences, Hasanuddin University, \\ Indonesia
}

\begin{abstract}
This study aims to explain the Strategic Design of the Regional Government in Tanjung Bira tourism development in Bulukumba Regency. This research method is qualitative with the type is a case study. Data collection in this study was carried out directly through observation and interviews. Data analysis was carried out through data reduction, data presentation and conclusion drawing. The results show that the government's strategic design in tourism development can still be less than optimal, which lies in the ineffective Tanjung Bira Tourism Development Planning and the unavailability of development land. Planners need to be extra careful about how they participate in strategic planning activities. This is based on the fact that not all approaches have the same use. Strategic design with land availability indicators is very necessary to arrange land zoning for the designation of new tourism development.
\end{abstract}

Keywords: Strategic Design, Local Government, Tourism Development

Received: April 15, 2021

Revised: May 27, 2021

Accepted: June 16, 2021

\section{Introduction}

Tourism in the development of the country basically consists of three aspects, namely the first from the economic aspect, sources of foreign exchange, taxes, the second social aspect of job creation, and the third aspect of culture introducing culture to foreign tourists (Hannam \& Knox, 2010; Spirou, 2011; Frey, 2007). , 2013). Tourism is one of the new style industries, which is able to provide rapid economic growth in terms of employment opportunities, income, standard of living and in activating other production sectors by tourist recipients (Eadington \& Smith, 2016; Nuraini, 2020).

The tourism sector is able to create new jobs. The regions are indirectly able to absorb more workers, so that by themselves they can increase the level of welfare of the people who are evenly distributed nationally. To provide direction for the development and development of the tourism sector, the government takes strategic policies as outlined in Government Regulation Number 50 of 2011 concerning the Master Plan for National Tourism Development through the ministry of tourism and the creative economy. One of the priorities set is marine tourism.

One of the most charming tourist attractions is Tanjung Bira which offers white sandy beaches with stunning coastal panoramas. Geographically, this beach is located at the southern tip of South Sulawesi province, precisely in Bontobahari District, Bulukumba Regency, with a distance of $21 \mathrm{~km}$ from the city of Bulukumba or $200 \mathrm{~km}$ from the city of Makassar.

There are many tourist objects that can attract tourists, both local and foreign tourists. The Bulukumba Regency Government through the Department of Culture and Tourism introduces tourist objects in Bulukumba Regency and improves the infrastructure of each tourist attraction in order to encourage the interest of domestic and foreign tourists.

Tourism planning in Bulukumba Regency is absolutely carried out so that it can optimize the benefits of activities and avoid or minimize problems that may arise. In addition, tourism 
development goals will be easier to achieve effectively if planning is carried out properly and integrated with regional and national development plans as a whole. However, tourism planning must be made in accordance with the characteristics of tourism

\section{Methods}

The research method used by researchers in this study is a qualitative method. The type of qualitative research used by researchers in this study is a case study. The object or location of this research is Tanjung Bira tourism as one of the most famous tourist objects in the archipelago to foreign countries. The focus of research is the concentration of concentration on the purpose of the research to be carried out so that it must be disclosed explicitly to facilitate researchers before making observations. Regional government strategy design, there are 2 indicators, namely tourism development planning and land availability. The unit of data analysis in this study is related organizations/institutions based on objective considerations to describe research on tourism development policy strategies in Bulukumba Regency. In this case, the unit of analysis is the Department of Tourism and Culture of Bulukumba Regency. Data collection in this study was carried out directly through observation and interviews. Data analysis was carried out through data reduction, data presentation and conclusion drawing.

\section{Results and Discussion}

\section{Tourism Development Planning}

From the results of research in the field, it was found that Strategic Tourism Planning as One of the Determinants of Public Policy Management on Tanjung Bira Tourism Development, Bulukumba Regency was not good enough, not in line with expectations, and still did not make a positive contribution to tourism development as a whole. Currently, the Tanjung Bira regional government, Bulukumba Regency, has carried out various corrections, anticipations, and synergies with various interested parties to support the development of tourism in Tanjung Bira, Bulukumba Regency as a whole, but the results are still not optimal.

Furthermore, the Bulukumba Regency Government develops an early warning system to avoid threats or develop strategies that can turn threats into profits. Without systematically researching and diagnosing strategic factors, the time pressures of the task of managing the organization lead to inadequate responses to environmental changes. Because of the difficulty of assessing the future, not all future events can be anticipated perfectly. However, there are some events to some extent that can be anticipated through the process of analysis and diagnosis of strategic factors. This process will reduce the time pressure for things that can be anticipated in advance so that organizational managers can focus on only essential problems rather than having to think about all environmental opportunities and threats in a very limited setting.

After the researchers conducted research in the field, it was found various kinds of problems regarding strategic planning in relation to the development of tourism in Tanjung Bira, Bulukumba Regency. According to the researcher, in an effort to achieve the goals that must be achieved, a basic strategy is needed which is generally an effort to minimize weaknesses, reduce obstacles and take advantage of existing opportunities and strengths. For this reason, it is necessary to review several problems of tourism development in general.

Planning is a way or technique to achieve the desired goals in the development process so as to be able to realize an advanced, prosperous and prosperous society. Planning is a concept that is planned and arranged systematically by a particular agency in order to achieve a goal. Planning is the selection and determination of activities, then what to do, when, how and by 
whom. Planning is a process that does not end when the plan has been determined and must be implemented.

The results of interviews in this study confirm the existence of adequate tourism infrastructure as a condition for increasing the growth rate of the tourism sector. "Development of transportation, information, and lodging facilities is very much needed in attracting foreign tourists. The infrastructure will make it easier for people to move around. The movement of people, he said, was always followed by the movement of goods, services and money. Travel itself is identical with the movement of people from one city to another or from one country to another, the infrastructure is not only toll roads, but also airports and ports. With more complete airport and port facilities, access to tourist destinations is also increasingly open.

Tourism planning is a decision-making process related to the future of a tourist destination or tourist attraction which is a dynamic process of determining goals, which systematically considers various alternative actions to achieve goals, implementation of selected alternatives and evaluation. The tourism planning process by looking at the environment (physical, economic, social, political) as a component that is interrelated and interdependent with one another (Paturusi, 2008).

Tourism planning uses general planning concepts that have proven effective in dealing with modern development processes, but adapts to certain tourism characteristics. The tourism planning approach leads to practical application in policy formulation and tourism development. The basic planning process described before provides a general planning framework and emphasis is placed on the concept of planning to be sustainable, systemsoriented, comprehensive, integrated, and environmental with a focus on successful development that can support community involvement. (Inskeep, 1991).

Strategic Planning of Tourism as One of the Determinants of Public Policy Management on Tourism Development in Tanjung Bira, Bulukumba Regency has a significant impact, although not optimal, this is in line with the opinion of Mintzberg (1994) as follows: "Strategy: is a plan; is a pattern; is a position; is a perspective". While Kreitner (1992) states: "Strategy is the pattern of decision of organization makes", and according to Certo et al. who quoted Quinn's opinion, stated that: "Strategy as pattern or plan that integrates an organization's major goals, policies, and action sequences into a cohesive whole".

Although the planning activity is the most critical activity compared to other activities, people still carry out planning activities, because planning after all has enormous benefits for the survival of the organization. The uses of the planning, among others, are as follows: (a). guidelines and implementation of controls; (b). avoid wasting resources; (c). tools for improving "quality assurance" and (d). efforts to fulfill institutional accountability.

Bahar (2003) states that planning is the foundation for a manager's job performance and is always aimed at the future. Given that the future is full of uncertainty, because humans cannot know for sure what will happen in the future, humans are forced to make predictions or make predictions about it.

Planning is a primary management function that is fundamental in nature and through planning it is possible to reduce uncertainty, because future events, as a result of internal and external influences that often change so that they are difficult to control, can be anticipated within reasonable limits. considered possible. Rosadi \& Maryana (1998) stated that planning is essentially an attempt to anticipate these changes and design an environment for an effective performance for the organization, where the most essential task is to see that the goals and objectives and the methods to achieve them are clearly understood by all. parties involved in the organization. 
In the implementation of planning, several dimensions are used as the basis for measuring success and at the same time contributing to the implementation of tourism development in Tanjung Bira, Bulukumba Regency, namely (1) the main expectations of the interests of internal parties, (2) the main expectations of the interests of outsiders, (3) the basis for data, and (4) coordination. In a plan carried out by the Tanjung Bira government, Bulukumba Regency related to tourism development, it contains the following dimensions; (1) The main hope is the interests of outsiders, meaning that there is support from the local government for business activities and providing quality services; (2) The main hope of the interests of the insider, which means always paying attention to the development and promotion of its employees, improving the standard of living by implementing an employee training system and adequate employee benefits; (3) Database, meaning matters relating to local government policies in providing regional tourist attraction facilities, coordination patterns and the availability of tourist attractions through guide books; (4) Master strategy, meaning the determination of organizational policies and goals; (5) Implementation, meaning the implementation of all policies including the division of labor, delegation of authority and responsibility.

Planning is the process of utilizing related facts and future assumptions to formulate a series of actions that will be implemented in order to achieve specific goals (Gollwitzer et al., 2004; Bradfield et al., 2005). Strategic planning includes the steps taken by managers to allocate resources to activities that outline the relationship of the organizations concerned with their environment (Ireland et al., 2001; Allison \& Kaye, 2015). Another understanding of strategic planning as stated by Steiner (1997) that Strategic planning is the systematic and more or less formalized effort of a company to establish basic company purposes, objectives, policies, and strategies and to develop detailed plans to implement policies and strategies to achieve objectives and basic company purposes.

Although strategic planning can provide all of the above benefits, there is no guarantee that everything will work. This is because strategic planning is just a set of concepts, procedures, and tools. Here planners need to be extra careful about how they participate in strategic planning activities. This is based on the fact that not all approaches have the same use, because various conditions are needed that will affect the success of using each approach.

Back to Steiner (1997) which states that strategic planning is basically referred to as "Plan to plan" (plan to plan). This implies that strategic planning is basically a derivative plan or elaboration of a plan made by top management (policy level).

To explain this "Plan to plan", return to Bromley's opinion in his book Economic Interests and Institutions, which describes that the level of policies made by high-level organizations is a policy which, when viewed from the point of view of its objectives, has a general, relative, and "nothing" character. time horizone" (no time limit).

\section{Tourism Market Problems}

The Tanjung Bira Tourism Marketing System in Bulukumba Regency has not yet focused on the right market share. This is because a careful research has not been carried out, so that matters relating to strategic plans and marketing programs, development of marketing organizations, development of marketing information systems and systems of monitoring/controlling marketing activities are still instinctive and have not been contained in a Blue Print of marketing plans that patterned.

In addition to the problems above, another thing that needs to be considered is the potential for tourist destinations such as Yogyakarta, Bali, East Java, Central Java, North Sumatra, Lombok which have a stronger appeal. The existence and development of tourism in these areas must 
be observed on an ongoing basis so that Tanjung Bira, Bulukumba Regency can compensate and be able to display or develop tourist objects and attractions that can attract as many tourists as possible to visit.

Marketing organizations at the local level and Bulukumba Regency, have not utilized optimal cooperation and coordination with marketing organizations at the national, regional and international levels so that a marketing organization forum that involves various parties is needed, so that it can intensively drive the tourism marketing system of Tanjung Bira Regency. Integrated and sustainable Bulukumba.

\section{Problems with Tourist Object and Attractions}

The potential for tourism objects in Tanjung Bira, Bulukumba Regency has a fairly high attraction and has a fairly complete diversity, this is a potential that must be maintained and developed. The objects and attractions are natural objects and attractions, cultural objects and attractions, and human objects and attractions.

Investors' interest in developing natural and cultural assets is still low, because it is seen that investment in these assets lacks high economic value. And some potential and functional assets are not developed and utilized optimally, because most of their management is handled by village community institutions or untrained personnel. Another thing is the potential for objects and tourist attractions made by humans such as cultural tourism objects that cannot yet become regular tourist attractions, including there are no routine arts events because so far they are displayed based on orders and the problem of the licensing process is still difficult, the amount of taxes, as well as the lack of facilities and performance facilities for the public.

\section{Transportation Problems}

The presence of the airport in Tanjung Bira, Bulukumba Regency, will be beneficial for increasing the flow of tourists to Tanjung Bira, Bulukumba Regency. In this case, we need a way through to the potential objects and tourist attractions of Tanjung Bira, Bulukumba Regency. Another problem is that the population mobility is quite high, resulting in parking facilities for tourists that are still not supportive, resulting in high traffic density having to compete with other economic activities. As a result, the traffic density is too high.

\section{Problems of Tourism Facilities and Services}

The lack of a well-directed location and agglomeration resulted in the average filling of hotel rooms not meeting expectations, this resulted in the development of supply exceeding existing demand. The travel business has not been able to create and sell new products, besides that there are not enough skilled workers in this field. The promotions that have been carried out have not provided information and directories to tourist objects so that their potential is less known to tourists. Another problem is the uneven cost of hotel and villa rates, causing local tourists and tourists outside the Bulukumba area to be reluctant to return to visit Tanjung Bira.

\section{Not Optimal and Integrated Utilization of Tourism Objects}

This happens because there is no opportunity in the development of tourist routes, both within each Tourism Development Area (WPW) and between WPWs. As a result, the existing potential does not support each other, even kill each other.

\section{Availability of Development Land}

The principle of natural area design is the basics of structuring the area including aspects that need to be considered and components of structuring the area. Gunn and Var, (2002) suggest that a good and optimally successful tourist area is based on four aspects, namely: 1) Maintaining environmental sustainability, 2) Improving the welfare of the community in the 
area, 3) Ensuring visitor satisfaction, 4) Increasing integration and community development unit around the area and development zone.

The arrangement of natural tourism areas includes the determination of land allocation which is divided into three, namely: 1) preservation zone, 2) conservation zone, 3) utilization zone. According to Rijksen (1981), conservation is a form of cultural evolution or cultural change where in the past, conservation efforts were worse than today. Meanwhile, according to Wayne Attoe (1979), what can be conserved is the natural environment (such as coastal areas, forests, mountain slopes and archaeological sites), urban and rural areas, skyline and regional corridor tourism, the front of a building (facade) and buildings and elements from the building.

McHarg (1971) in selecting areas that are intrinsically suitable for conservation, several factors are determined, namely: historically valuable features, high quality forests and swamps, bay coast features, rivers, habitat for wild animals, unique geological and physiographic appearances, views of the waters with good tourism and rare forms of ecological relevance. According to Bovy M, Lawson (1977), the development of natural tourism areas must follow the principles of development and planning for the use of areas consisting of spatial or zoning subsystems, namely: 1). Allotment of public facilities, permanent buildings, recreation, tourism and sports facilities. 2). Allotment of non-permanent facilities, camping, fishing, and so on. 3). The construction of public transport roads is not allowed. Intended for walking trails, climbing, equestrian sports \& tourist substations. 4). There is no access road. According to the researcher, according to the field of strategic design strategies with indicators of land availability, it is very necessary to arrange land zoning for allotment of new tourism development.

\section{Conclusion}

The Government's strategic design in tourism development can still be less than optimal, which lies in the ineffective Tanjung Bira Tourism Development Planning and the unavailability of development land. The government must conduct a special evaluation related to the implementation of the technical plan for the development of the Tanjung Bira tourism area which was prepared about 10 years ago, so that the government can measure the level of success of the technical plan.

\section{References}

Allison, M., \& Kaye, J. (2015). Strategic planning for nonprofit organizations: A practical guide for dynamic times. John Wiley \& Sons.

Bahar, M. (2003). Misconceptions in biology education and conceptual change strategies. Educational Sciences: Theory \& Practice, 3(1), 55-64.

Bradfield, R., Wright, G., Burt, G., Cairns, G., \& Van Der Heijden, K. (2005). The origins and evolution of scenario techniques in long range business planning. Futures, 37(8), $795-$ 812.

Eadington, W. R., \& Smith, V. L. (2016). Introduction: The emergence of alternative forms of tourism. In Tourism alternatives (pp. 1-12). University of Pennsylvania Press.

Frey, B. S. (2013). Arts \& economics: Analysis \& cultural policy. Springer Science \& Business Media.

Gollwitzer, P. M., Fujita, K., \& Oettingen, G. (2004). Planning and the implementation of goals (pp. 211-228).

Hannam, K., \& Knox, D. (2010). Understanding tourism: A critical introduction. Sage. 
Inskeep, E. (1991). Tourism planning: An integrated and sustainable development approach. John Wiley \& Sons.

Ireland, R. D., Hitt, M. A., Camp, S. M., \& Sexton, D. L. (2001). Integrating entrepreneurship and strategic management actions to create firm wealth. Academy of Management Perspectives, 15(1), 49-63.

Kreitner, K. (1992). Minstrels in Spanish churches, 1400-1600. Early music, 20(4), 533-546.

Mintzberg, H. (1994). Rounding out the manager's job. Sloan Management Review, 36, 11-11.

Nuraini, F. R. (2020). Control of Alcoholic Drinks Distribution in Supporting Tourism Business. Journal La Bisecoman, 1(4), 9-18.

Paturusi, S. A. (2008). Perencanaan Kawasan Pariwisata. Denpasar: Press UNUD.

Rosadi, D., \& Maryana, D. (2001). Determinan Peningkatan Pendapatan Asli Daerah: Sistem Perencanaan Terpadu. Sosiohumaniora, 3(1), 52.

Spirou, C. (2011). Urban tourism and urban change: Cities in a global economy. Routledge.

Steiner, G. A. (1997). Strategic planning. a step by step guide. New York: The Free Press 